\title{
New Insights into the Gametogenesis of Biomphalaria glabrata (Mollusca, Gastropoda, Pulmonata): Implications for Histopathological Assessment
}

Cândido Carvalho Rodrigues ${ }^{1}$

https://orcid.org/0000-0002-8457-708X

\section{Maxwell Batista Caixeta ${ }^{1}$}

https://orcid.org/0000-0001-6260-1571

Thiago Lopes Rocha ${ }^{1^{\star}}$

https://orcid.org/0000-0003-0551-6842

${ }^{1}$ Federal University of Goiás, Institute of Tropical Pathology and Public Health, Laboratory of Environmental Biotechnology and Ecotoxicology, Goiania, Goiás, Brazil.

Editor-in-Chief: Paulo Vitor Farago

Associate Editor: Marcelo Ricardo Vicari

Received: 2020.09.02; Accepted: 2021.02.24.

*Correspondence: thiagorochabio20@ufg.br (T.L.R.)

\section{HIGHLIGHTS}

- The gametogenesis of Biomphalaria glabrata was described.

- Oogenesis was classified into five developmental stages.

- New histomorphometric parameters were described for oocytes.

- Spermatogenesis was classified into seven stages of development.

- B. glabrata histomorphometric parameters as a tool for environmental and public health researches.

Abstract: The reproductive system has a fundamental role in population dynamics and several reproduction strategies have been shaped by the environment over time. Many environmental pressures are generated by releasing pollutants, as endocrine disruptors, that can affect the reproductive system of individuals, among them invertebrates. The freshwater snails Biomphalaria spp. are used as biomonitor in several ecotoxicological studies; however, there are few studies about gametogenesis and morphology of reproductive snail cells, which could be used as a new biomarker. In this sense, the current study aims to characterize Biomphalaria glabrata gametogenesis, bringing new histomorphometric parameters for germinative cells. Results showed that the hermaphrodite tissue is formed by several acini with simple pavement epithelium with germinative and somatic cells. Oogenesis was classified into five developmental stages (OI to OV) according to diameter, nucleus area, total area, and follicular cell development, and then classified into previtellogenic and vitellogenic oocytes. The spermatogenesis was classified into spermatogonia (Spg), spermatocytes (Spc) and spermatids that were subdivided into five stages (Spt I to Spt V) according to cytoplasm losing, and nucleus spiralization along with Sertoli cells development. Thus, the 
present study highlights the gametogenesis of $B$. glabrata with new histomorphometric parameters, which can be an important tool for ecotoxicological and molluscicidal developmental further studies.

Keywords: hermaphrodite; freshwater snail; histomorphometry; oogenesis; spermatogenesis.

\section{INTRODUCTION}

The morphological complexity of the hermaphroditic reproductive system, the high influence of environment gametes maturation, and the high diversity of gastropod reproductive strategies reflect their life history strategies [1,2]. Hermaphroditism is widespread in the Class Gastropoda, and it is an important evolutionary strategy, since from a few individuals, through self-fertilization (or cross-fertilization) mechanisms, species can quickly establish new populations and colonize a new environment $[3,4]$. This strategy is present in a lot of snails of medical and veterinary importance, that acts as intermediate hosts of parasites, such as Biomphalaria glabrata, Lymnaea stagnalis, Physella acuta and Cornu aspersum, which are also widely studied as model systems in ecotoxicology due to their fast life cycle and population density [5-7].

The freshwater snails Biomphalaria spp. have been one of the widely used invertebrate model system in laboratories [8-16], mainly due to their short life cycle, ease of maintenance and reproduction [9,10]. A lot of research has used the snail as a biomonitor in ecotoxicological risk assessments due to its high sensibility to several aquatic pollutants [8,11-15]. Also, invertebrates make up most of the fauna in aquatic environments [17] and may be used to assess the mode of action (MoA) and ecotoxicity of endocrine-disrupting chemicals (EDCs) [10, 18-20]. The EDCs can decrease the reproduction, fertility, fecundity, hatching ratio, alter the synthesis and metabolism of hormones or their receptors, change the behavior and development, or induce histopathological alterations in the snail gonads [21-25]. The gonad (ovotestis) is a crucial organ for understanding the effects of EDCs on the aquatic environment in different species and may offer several histopathological biomarkers [26,27].

The hermaphrodite snail $B$. glabrata can use the endogenous sperm (autosperm) to self-fertilize or the exogenous sperm (allosperm) to cross-fertilize. However, grouped snails prefer to copulate and reproduce by cross-fertilization $[28,29]$. Significant advances in the knowledge of reproduction in $B$. glabrata have been made in the last decade, especially associated with qualitative histological, ultrastructural, and metabolically analysis after parasitic infection [30-32]. However, due to the increasing use of the B. glabrata as a model system in toxicology and ecotoxicology [19,33,34], the description of the gonadal histomorphometric parameters is important to complement the analyses with the qualitative histopathological biomarkers.

Accordingly, the present study aimed to characterize the gametogenesis of $B$. glabrata by qualitative and quantitative histological assessment, as well as to provide detailed information on the gonadal structure. A series of detailed photomicrographs and a schematic model of the gametogenesis of $B$. glabrata are presented. Furthermore, the knowledge of the morphological characteristics of gonads also helps to understand the MoA and toxicity of potential molluscicides, bringing important information for studies related to the development of new compounds for the control of schistosomiasis-transmitting snails.

\section{MATERIAL AND METHODS}

\section{Snails}

Adult snails $B$. glabrata (BH strain) with a shell diameter of $10 \pm 2 \mathrm{~mm}$ and a total weight of $0.28 \pm 0.04$ $\mathrm{g}$ were obtained in the Institute of Tropical Pathology and Public Health from the Federal University of Goiás (UFG - Brazil) and maintained in laboratory conditions accordingly to Organisation for Economic Cooperation and Development (OECD) guideline $\mathrm{n}$ - 243 [35]. Snails were maintained in tanks filled with $20 \mathrm{~L}$ of dechlorinated water under controlled conditions of temperature $\left(26 \pm 1^{\circ} \mathrm{C}\right), \mathrm{pH}(7.0 \pm 1)$ and photoperiod (12:12h light/ dark cycle). Snails were fed ad libitum three times per week with fresh lettuce leaves.

\section{Histology and histomorphometry}

The snails $(n=18)$ were euthanized by a puncture in the pericardial cavity using a disposable syringe to collect hemolymph. The gonad was carefully dissected and immediately fixated by immersion in $4 \%$ paraformaldehyde buffered solution for four hours under agitation. Afterward, gonads were dehydrated through increasing ethanol gradient, embedded in glycol-methacrylate resin (Historesin, Leica, Germany), sectioned into $2.5 \mu \mathrm{m}$ thick slices ( 3 slides per snail; 10 sections per slide; totalizing 540 sections) and stained 
with $1 \%$ Toluidine blue (TB) at $\mathrm{pH}$ 8.5. Histological assessment and digital image capture were performed in the light microscope (Leica DM 750) associated with software Leica ICC50 HD).

For qualitative and histomorphometric analyses, images of gonad sections were randomly captured at $200 x$ magnification and analyzed using the Image $\mathrm{J}$ software (version 1.46r - 64 bits). The following histomorphometric parameters were analyzed: (I) Number of previtellogenic and vitellogenic oocytes; (ii) Smaller and larger diameter of oocytes; (iii) Total and nuclear area of oocytes; (iv) Nucleus/cytoplasm ( $\mathrm{N}: \mathrm{C}$ ) ratio. Also, oocytes were classified as previtellogenic (OI and OII) and vitellogenic (OIII, OIV, OV) according to the increasing yolk granules. The morphology of gametogenesis (oogenesis and spermatogenesis) and vitellogenic process were analyzed according to previous studies with B. glabrata [36-39] and other gastropods $[40,41]$.

\section{Statistical analysis}

Statistical analyzes were performed using the RStudio software (RStudio team, 2015), using normality and homoscedasticity tests for all data using the Shapiro-Wilk and Levene tests, respectively, and the Tukey test was performed posteriorly. Subsequently, the Kruskal Wallis, Spearman correlation and Kendall-Theil regression test was performed using $p$-value $=0.05$.

\section{RESULTS AND DISCUSSION}

\section{Morphology of B. glabrata}

External morphology and the anatomy of the hermaphrodite gonad of B. glabrata are show in Figure 1. $B$. glabrata has a brownish-colored shell with biconcave disc form, non-operculated and flat-spiral with a sinistral orientation (Figure 1A). Adult individuals were reaching 20 to $40 \mathrm{~mm}$ in diameter, as previously described [38]. The hermaphrodite gonad (ovotestis) is located in the central gyrus shell (Figure 1B). Also, the reproductive system is widely used for taxonomic differentiation between species [42-44]. The reproductive system consists of cells, glands and channels that form the female clusters: vagina, vaginal pouch, spermatheca, uterus, nidamental gland, oviduct pouch, oviduct and albumen gland. Furthermore, several structures form the male clusters, such as penis and accessory structures (foreskin, protractor and retractor muscle of the foreskin), vas deferens, prostate, sperm channel and hermaphroditic structures $[38,45]$. In ovotestis, male and female germinal cells are produced, which are conducted to the collecting channel, and carried along to narrow ovispermiduct.

The male gametes accumulate and undergo maturation in the seminal vesicles. In contrast, the female gametes are conducted via ovispermiduct to a small bag called the genital crossroads or carrefour, which receives the secretion from the albumen gland involving the oocyte and which forks in the male and female branches. Also, male gametes are directed to the ovispermiduct, while female gametes are directed to the oviduct. Fertilization occurs in the uterus, and previously, in the carrefour, the oocyte receives the nutritive secretion from the albumen gland, travels through the oviduct pouch containing secretions from the nidamental gland forming groups encapsulated by these secretions called "ovigerous capsules" $[38,39,46,47]$. 


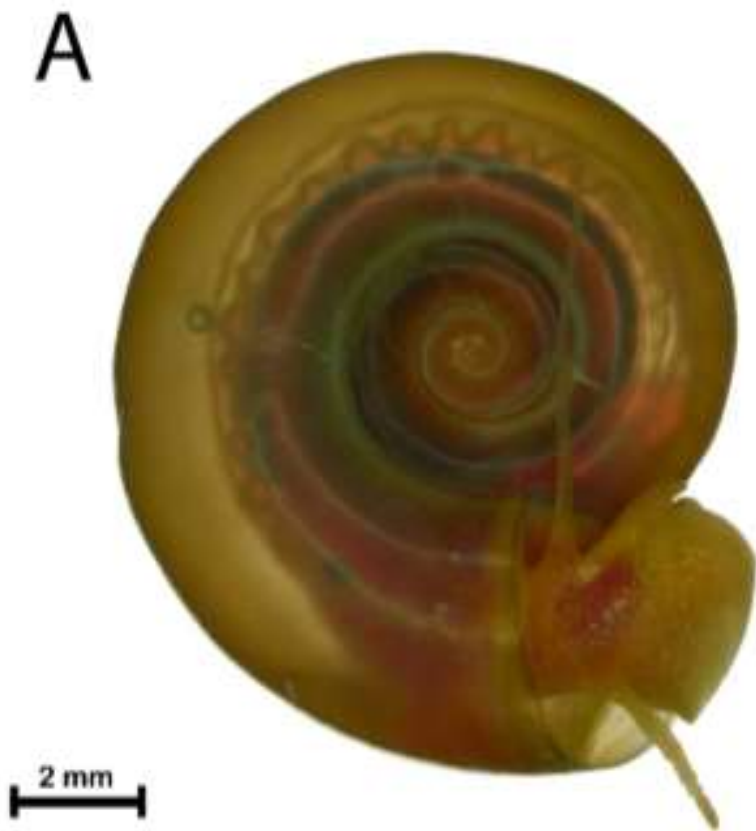

B

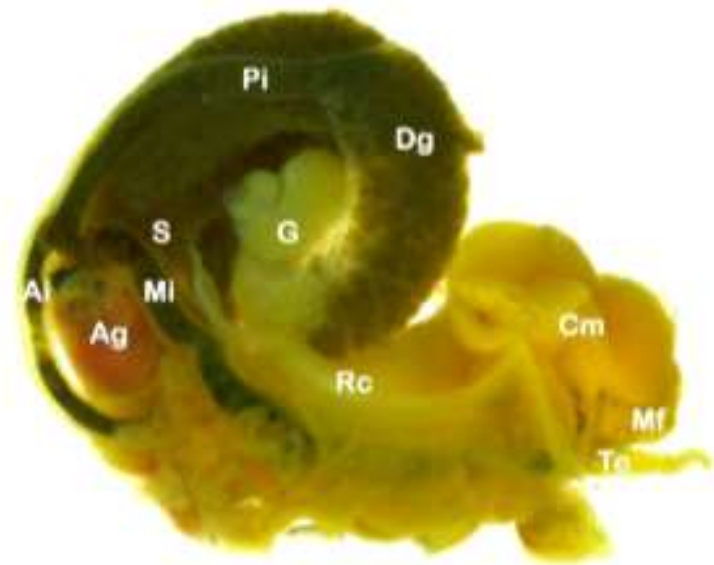

Figure 1. External (A) and internal morphology (B) of the freshwater snail Biomphalaria glabrata. (A) A whole animal showing shell, foot and tentacle. (B) Dissected snail showing gonad (G), digestive gland (Dg), medium intestine (Mi), posterior intestine $(\mathrm{Pi})$, anterior intestine $(\mathrm{Ai})$, stomach $(\mathrm{S})$, albumen gland $(\mathrm{Ag})$, renal crest $(\mathrm{Rc})$, cephalopodal mass $(\mathrm{Cm})$, tentacle (Te), Muffle (Mf).

\section{Histological characterization}

The histological assessment showed that the oogenesis and spermatogenesis of the $B$. glabrata occur in the same follicular acini (Figure 2), which is lined by a simple pavement epithelium and consists of acini that house the male gametes and Sertoli cells, as well as female gametes with follicular cells which together prevent self-fertilization, confirming their potential capacity of self-fertilization in stress periods and be resistant to periods of desiccation [48].
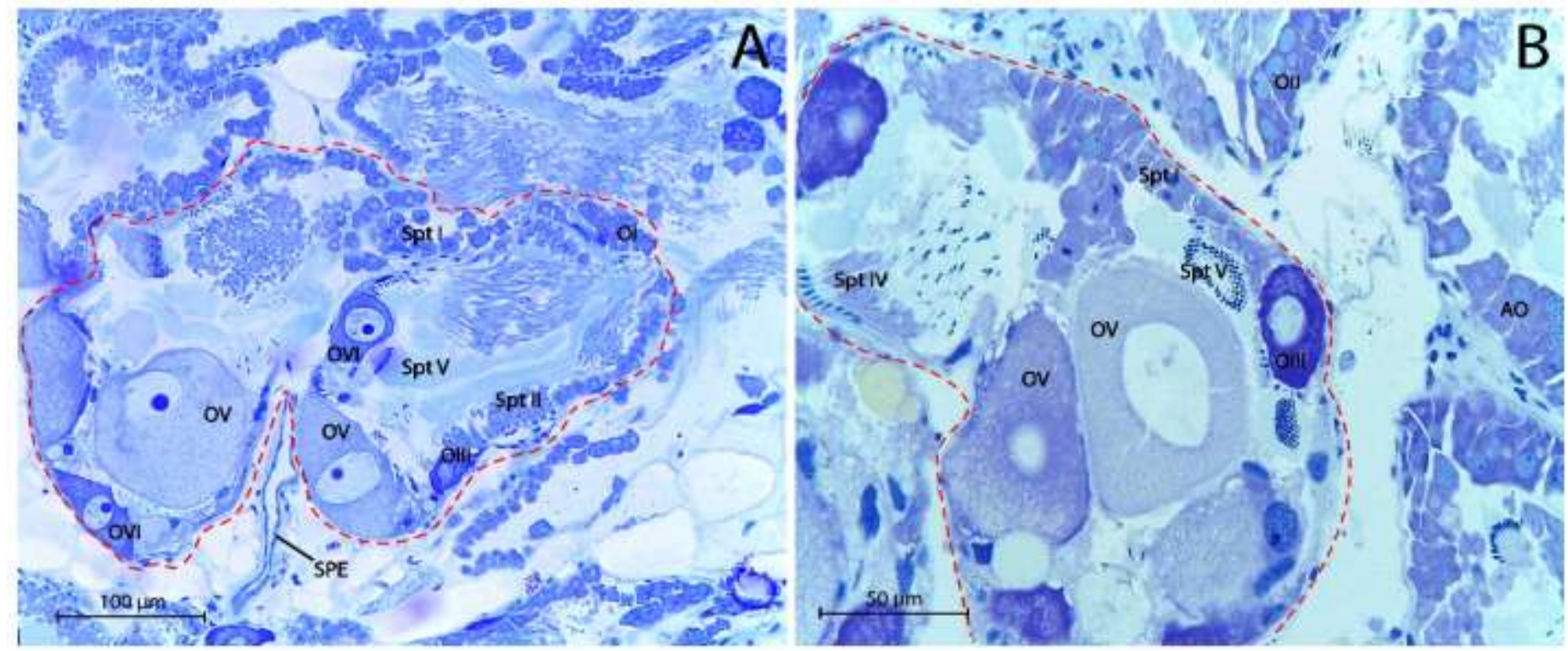

Figure 2. Photomicrograph of the hermaphroditic gonad of Biomphalaria glabrata snail. (A) Transversal section showing a general view of tissue (200x magnification). (B) Transversal section showing a more detailed view of acini $(400 x$ magnification). Scale bars: $A=100 \mu \mathrm{m} ; B=50 \mu \mathrm{m}$. Stage I oocytes (OI); stage II oocytes (OII); stage III oocyte (OIII); stage IV oocytes (OIV); stage V oocytes (OV); atresic oocytes (AO); Stage I Spermatids (Spt I); stage II spermatids (Spt II); stage IV spermatids (Spt IV); stage V spermatids (Spt V); simple pavement epithelium (SPE). The gonads were embedded in glycol-methacrylate resin and stained with $1 \%$ toluidine blue at $\mathrm{pH}=8.5$. 


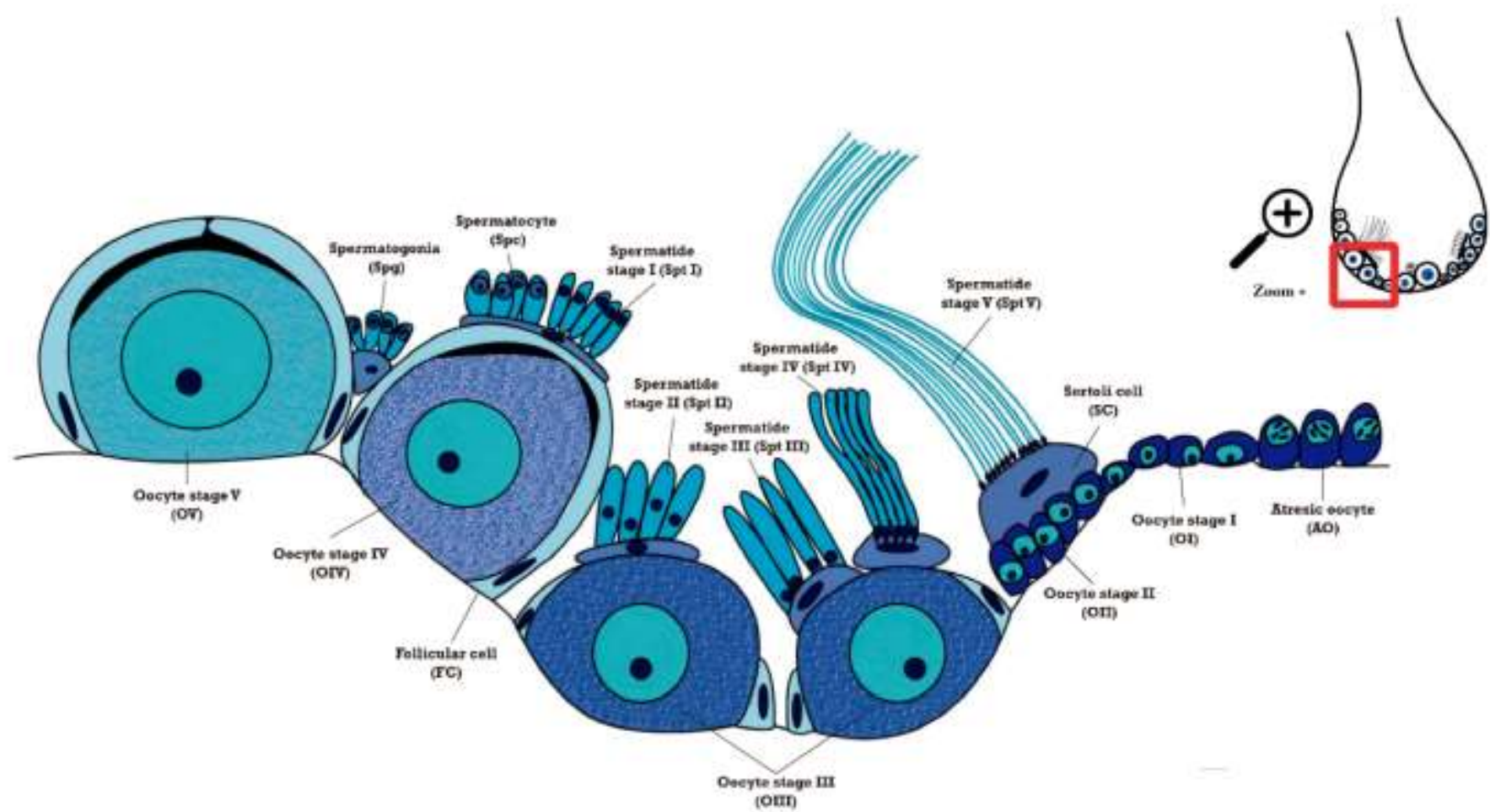

Figure 3. Scheme illustrating the oogenesis and spermatogenesis in the Biomphalaria glabrata. Size and color are not representative and should not be compared.

The gametogenesis in $B$. glabrata is a complex process characterized by cellular proliferation and differentiation (Figure 3), similar morphology was described for Biomphalaria alexandrina (Ehrenberg, 1831) [40] and for Helicodonta obvoluta (O. F. Müller, 1774) [41]. In this process, somatic cells (Sertoli cells) provide structurally and function support for survival, proliferation, and differentiation of germ cells, with are fundamental for spermatogenesis, being responsible for the transport of the apical to the basal part of the acini, nutrition, and development of spermatogenic cells, differentiating together, as well as the production of steroid hormones [37].

\section{Oogenesis}

Biomphalaria glabrata oocytes were classified into previtellogenic (OI, OII) and vitellogenic (OIII, OIV, OV) (Table 1; Figure 4). Previtellogenic oocytes were more frequent cells (87.8\%) compared to vitellogenic oocytes (Figure 5A). Previtellogenic oocytes are smaller in size and have a basophilic cytoplasm due to the low number of cytoplasmic granules and due to the accumulation of rRNA and heterogeneous RNA in the cytoplasm [36] (Figure 4A, B). The primary oocytes (OI) or oogonia are smallest cells (smaller diameter $=9.2$ $\pm 1.92 \mu \mathrm{m}$; larger diameter $=9.43 \pm 1.61 \mu \mathrm{m}$ ) (Figure $5 \mathrm{~B})$ with no follicular cells. Ol showed nucleus (area $=$ $50.80 \pm 6.93 \mu \mathrm{m}^{2}$ ) and nucleolus occupying most of the cytoplasm (area $\left.=85.71 \pm 16.20 \mu \mathrm{m}^{2}\right)$ (Figure 4A, B, 5B, C). The secondary oocytes (OII) (Figure 4A, B) (smaller diameter $=13.98 \pm 3.17 \mu \mathrm{m}$ and larger diameter $=15.09 \pm 3.90 \mu \mathrm{m})$ (Figure 5B) with basophilic cytoplasm, having an increase of total area $(197.25 \pm 39.33$ $\left.\mu \mathrm{m}^{2}\right)$ and nucleus area $\left(60.21 \pm 10.83 \mu \mathrm{m}^{2}\right)$. No significant difference was observed in the nuclear area of OI and OII. However, OI showed high nucleus/cytoplasm compared to OII ( $<<0.05$; Figure 5D), confirming the increase in the cytoplasm areain Oll due to the presence of cytoplasmic granules. 

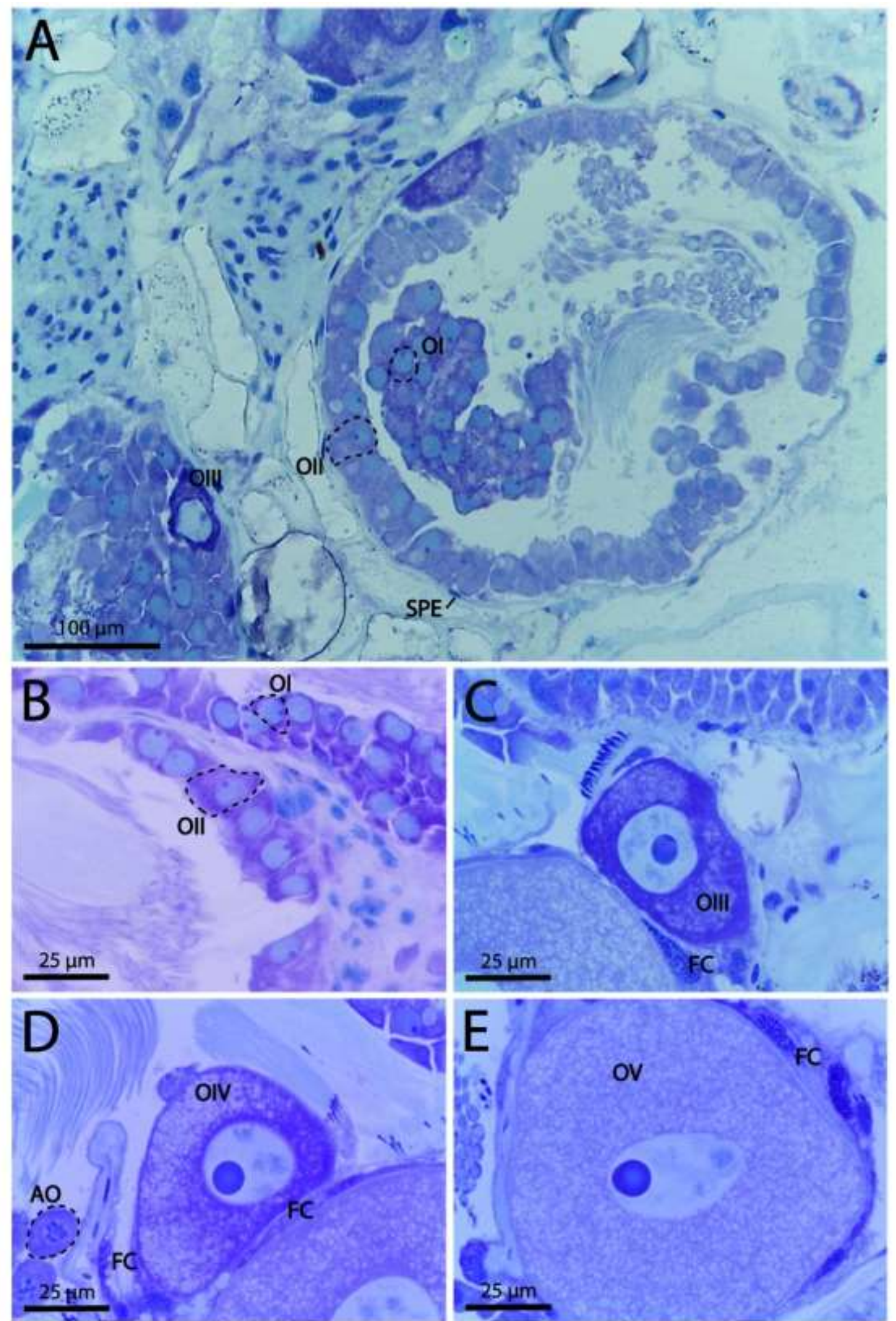

Figure 4. Oogenesis in the Biomphalaria glabrata. A. Stage I oocytes (OI), stage II oocytes (OII), stage III oocyte (OIII) and simple pavement epithelium (SPE). B. OI and OII; C. OllI and follicular cell (FC); D. stage IV oocyte (OIV), atresic oocyte (AO) and FC. E. Stage V oocyte (OV) and FC. (A-E). The gonads were embedded in glycol-methacrylate resin and stained with $1 \%$ Toluidine blue at $\mathrm{pH}=8.5$. 


\section{A}

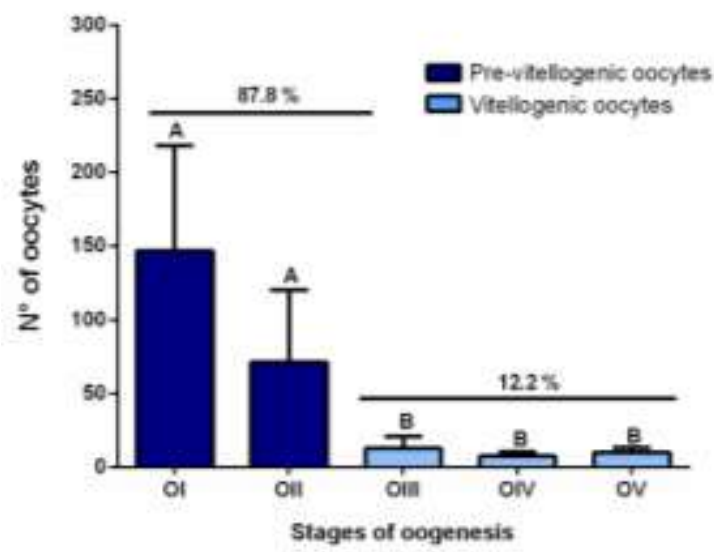

C

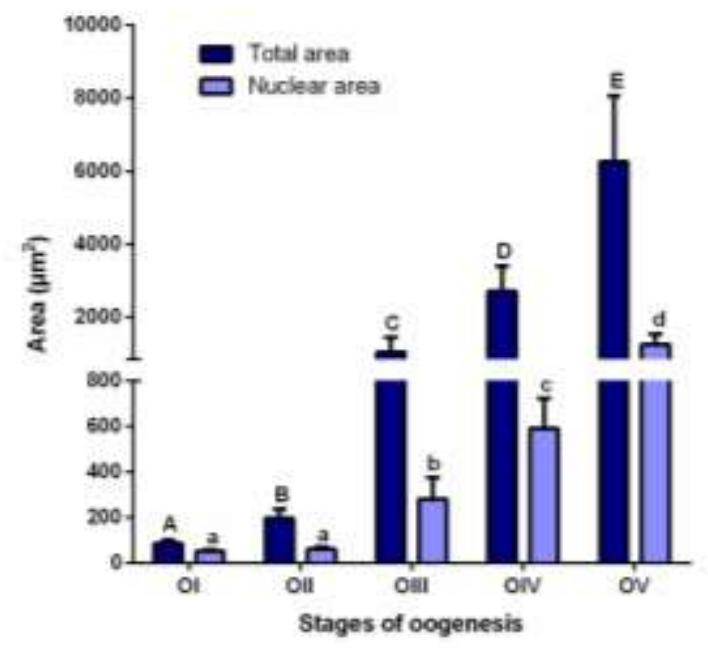

B

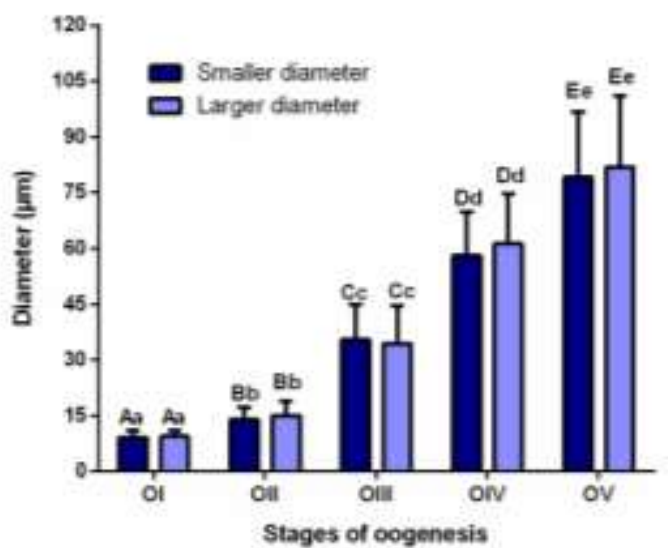

D

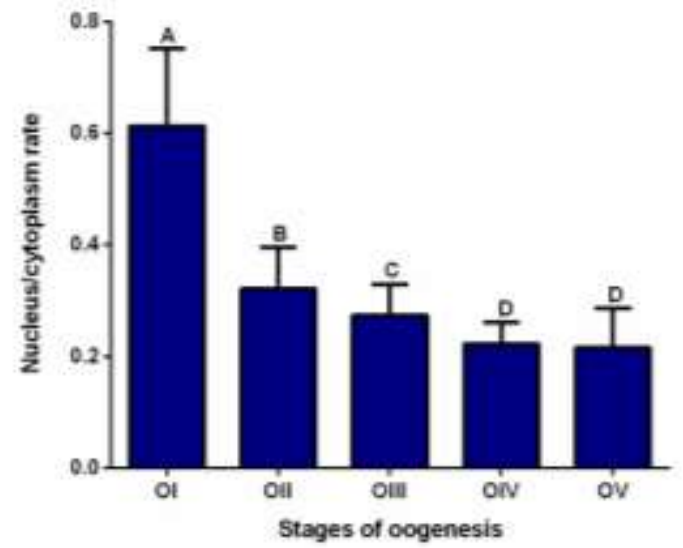

Figure 5. Quantitative parameters of oocytes of the Biomphalaria glabrata during different stages of oogenesis. A. The number of previtellogenic and vitellogenic oocytes; B. Horizontal and vertical diameter of oocytes; C. Total area and nuclear area of oocytes; D. Nucleus/cytoplasm ratio. Results are expressed as mean \pm standard deviation. Capital letters show differences between stages, while uppercase letters show differences in the same stage. 


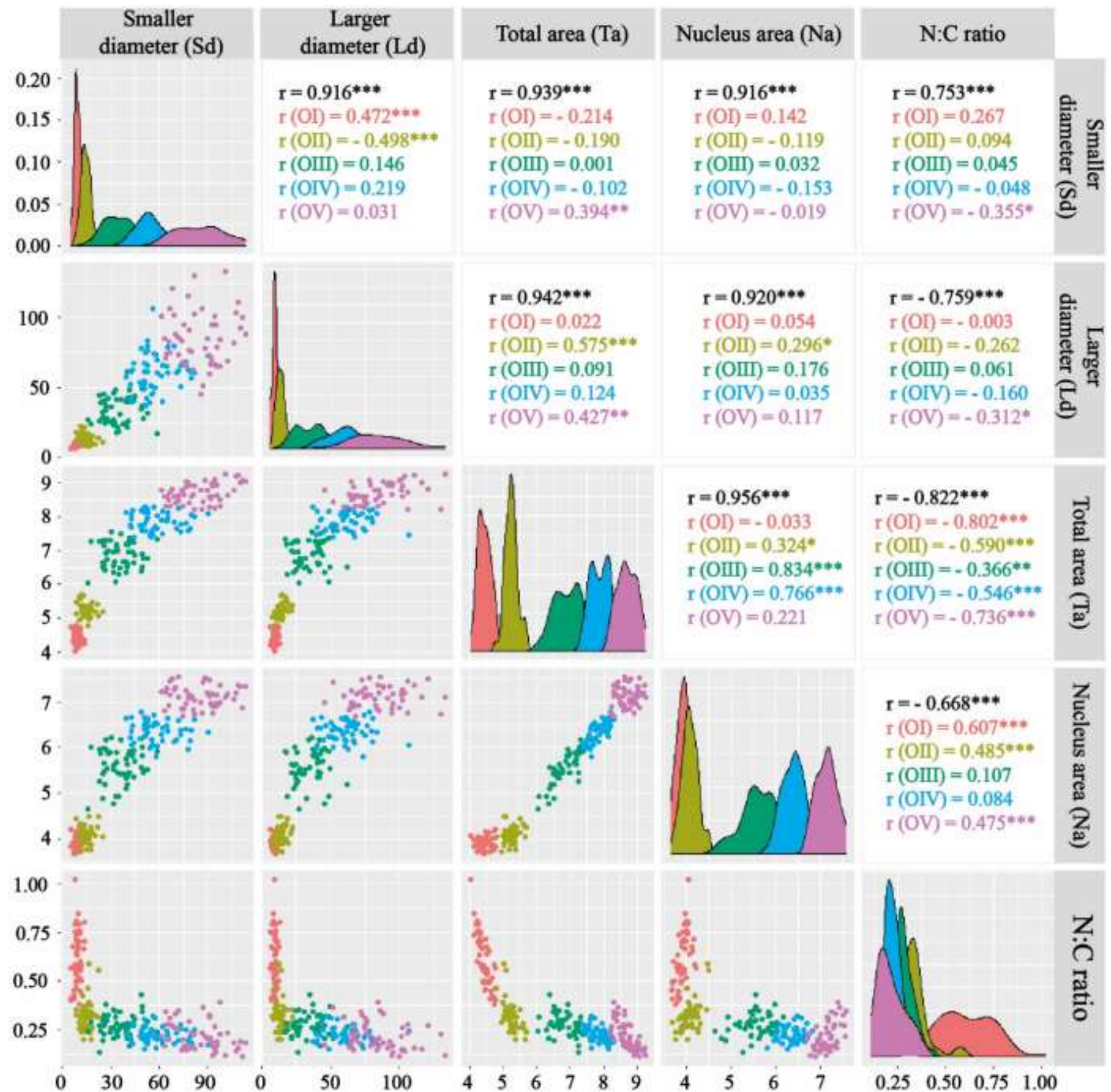

Figure 6. Spearman correlation of the quantitative parameters of oocytes of the Biomphalaria glabrata during different stages of oogenesis. The different stages of oocytes are represented in different colors: Stage I oocytes (OI): pink; stage II oocytes (OII): brown; stage III oocyte (OIII): green; stage IV oocyte (OIV): blue; and stage V oocyte (OV): purple. pvalue $<0.05\left(^{*}\right) ; p$-value $<0.01\left(^{* *}\right) ;$ and $p$-value $\left.<0.001{ }^{* * *}\right)$.

Vitellogenic oocytes feature an linear increase of smaller diameter and larger diameter over oogenesis $(\mathrm{Ld}=0.9388 \mathrm{Sd}+1,3991 ; r=0.916 ; p<0.05)$, also featuring an evident increase of total area and nucleus area with a linear increase over oogenesis $(\mathrm{Ta}=4.5101 \mathrm{Na}-121.3328 ; r=0.956 ; p<0.05)$, and loss of cytoplasmic basophilia due to increased presence of cytoplasmic granules throughout oogenesis (Figure 4 C-E; Figure 5 A-D; Figure 6). Vitellogenic oocytes are made up of tertiary oocytes (OIII) (Figure 4C) with an evident increase of diameter (smaller diameter $=34.50 \pm 10.08 \mu \mathrm{m}$ and larger diameter $=35.41 \pm 9.53 \mu \mathrm{m}$ ) (Figure 5B), total area $\left(1060.21 \pm 391.83 \mu \mathrm{m}^{2}\right)$, and nucleus area $\left(281.55 \pm 95.59 \mu \mathrm{m}^{2}\right)$ (Figure 5C) and presence of small follicular cells in development with a centralized nucleus. The quaternary oocytes (OIV) (Figure 4D) have smaller and larger diameters equal to $58.06 \pm 11.81 \mu \mathrm{m}$ and $61.22 \pm 13.44 \mu \mathrm{m}$ respectively (Figure 5B) with the total area and nucleus area equal to $2715.48 \pm 702.1 \mu \mathrm{m}$ and $591.21 \pm 130.14 \mu \mathrm{m}^{2}$, respectively (Figure $5 \mathrm{C}$ ), and have the presence of pavement follicular cells in development with an increase of cytoplasmic area and a lateralized elliptical nucleus; and mature oocytes (OV) (Figure 4E) have the biggest 
diameter (smaller diameter $=81.95 \pm 19.14 \mu \mathrm{m}$; larger diameter $=79.20 \pm 17.51 \mu \mathrm{m}$ ) (Figure 5B), total area $\left(6264.79 \pm 1788.96 \mu^{2}\right)$ and nucleus area $\left(1265.31 \pm 284.65 \mu^{2}\right)$ (Figure $5 \mathrm{C}$ ) with developed follicular cells.

During oogenesis, the nucleus of oocytes in the early developmental stages is large in relation to the total cell area, having a high nucleus/cytoplasm $(\mathrm{N}: \mathrm{C})$ ratio. The $\mathrm{N}: \mathrm{C}$ ratio decreased linearly in relation to total area $(\mathrm{N}: \mathrm{C}$ ratio $=-3.636 \mathrm{e}-05 \mathrm{Ta}+3.213 \mathrm{e}-01 ; \mathrm{r}-0.822 ; \mathrm{p}<0.05)$ and nucleus area over oogenesis $(\mathrm{N}: \mathrm{C}$ ratio $=32.8655 e-02 \mathrm{Na}+0.01729 \mathrm{e}-02 ; r=-0.668 ; p<0.05)$ (Figure 6). Previtellogenic oocytes have the higher $\mathrm{N}: \mathrm{C}$ ratio $(\mathrm{OI}=0.62 \pm 0.14$; Oll $=0.33 \pm 0.75)$ when compared to vitellogenic oocytes. Vitellogenic oocytes have a decrease of the $\mathrm{N}: \mathrm{C}$ ratio due to an increase of cytoplasmic volume, with OIII $=0.28 \pm 0.55$, getting lower on OIV and OV with the same N:C ratio (OIV $=0.22 \pm 0.039$; OV $=0.22 \pm 0.071$ ). The cell size is an important parameter for adaptability in the environment, having different mechanisms that control size by a variation of macromolecular synthesis depending of nutrient availability in the environment [49].

Table 1. Characterization of the oogenesis in the snail Biomphalaria glabrata (Say, 1818).

\begin{tabular}{ll}
\hline Stages & Description \\
\hline
\end{tabular}

\section{Previtellogenic}

Oocyte Stage I (OI)

Oocyte Stage II (OII)

\section{Vitellogenic}

Oocyte Stage III (OIII)

Oocyte Stage IV (OIV)

Oocyte Stage V (OV)
Oogonia with basophilic cytoplasm; absence of cytoplasmic granules and follicular cell; nucleus and nucleolus occupying most of the cytoplasm.

Oocyte with basophilic cytoplasm; a significant increase of cytoplasmic area. Nucleus and nucleolus areas don't present a significant increase in comparison with OI and occupy most of the cytoplasm.

Oocyte with an increase of cytoplasm eosinophilia by the presence of cytoplasmic granules, significant increase area of cytoplasm and nucleus; Presence of small follicular cell in development with a centralized nucleus.

Oocyte with eosinophilic cytoplasm and presence of cytoplasmic granules; a significant increase of cytoplasm and nucleus area; pavement follicular cell in development with a lateralized elliptical nucleus.

Oocyte developed with eosinophilic cytoplasm and cytoplasmic granules; follicular cells developed.

\section{Spermatogenesis}

Biomphalaria glabrata spermatogenesis was classified into three developmental stages (Spermatogonia - Spg; Spermatocyte - Spc; Spermatids - Spt) (Table 2; Figure 7). This classification was based on morphological characteristics, mitotic and meiotic process, performing the proliferation of male sexual cells, loss of organelles and half of the genetic material, and the inactivation of the nucleus by a process called histone transition, where lysine-rich histones are replaced by arginine-rich histones that act as genetic repressors [37]. The chronology of spermatogenesis was previously estimated [50] to be approximately 36 days (1-13 days, spermatogonia, 14-20 days, spermatocytes and 21-36 days, spermatids) and the morphology of Sertoli cells also changes considerably during all the spermatogenesis due to its essential role in the development of spermatozoids. 




Figure 7. Spermatogenesis in the Biomphalaria glabrata. A. Spermatogonia (Spg) and Sertoli cell (Sc). B. Spermatocytes (Spc) and Sc. C. Spermatids Stage I (Spt I) and Spermatids Stage II (Spt II). D. Spermatids Stage III (Spt III) and Sc. E. Spermatids Stage IV and V (Spt IV, Spt V) and Sc; F. Spermatids Stage V (Spt V) and Sc. (A-F). The gonads were embedded in glycol-methacrylate resin and stained with $1 \%$ Toluidine blue at $\mathrm{pH}=8,5$.

The first cell stage is the spermatogonia (Spg) (Figure 7A), which is pear-shaped with a nucleus in its apical portion, forming a cluster of Spg accompanied by a Sertoli cell in the shape of a bell. Spg and Sertoli cells start to differentiate, performing mitosis and both Spg and Sertoli cells being more elongated originating spermatocytes (Spc) (Figure 7B), which are cylindrical cells with a nucleus in their apical portion and accompanied by elongated Sertoli cells linked to the basal portion.

In the last developmental stage, the spermatocytes (Spc) perform a meiotic process and the histone transition, originating spermatids (Spt), which are elongated cells with condensate nucleus (Figure 7C - F). Spt is subdivided into five stages of development (Spt I, Spt II, Spt III, Spt IV, Spt V) according to the loss of cytoplasm, being more elongated after each stage and insertion of a nucleus in the Sertoli cell. In the first stage (Spt I) (Figure 7C), the cell starts to lose cytoplasm for the Sertoli cell, and the nucleus of these 
cylindrical cells begin to migrate to your basal part. In the second stage (Spt II) (Figure 7C), the nucleus almost reaches the basal portion of the cell, being more elongate with less cytoplasm accompanied by an elongated Sertoli cell with an increase of cytoplasmic volume. In the third stage (Spt III) (Figure 7D), the nucleus reaches the basal portion of the cell and, from that stage, the nucleus starts to be more elongated and start a spiraling process, well described by Transmission electron microscopy [37], for the insertion of spermatids on Sertoli cells. In the fourth stage (Spt IV) (Figure 7E), the cell finishes the spiraling process off the nucleus, showing a fusiform nucleus insert in an oval Sertoli cell. In the final stage of development (Spt V) (Figure 7E,F) the stage V spermatid or spermatozoa loses most of your cytoplasm for the Sertoli cell becoming a thin and elongated cell with a fusiform nucleus with a weak insertion in a big and oval Sertoli cell.

Table 2. Characterization of the Spermatogenesis in the snail Biomphalaria glabrata (Say, 1818).

Stages Description

Spermatogonia $(\mathrm{Spg})$

Spermatocytes (Spc)

Spermatids Stage I (Spt I)

Spermatids Stage II (Spt II)

Spermatids Stage III (Spt III)

Spermatids Stage IV (Spt IV)

Spermatids Stage V (Spt V)
Pear-shaped cells with a nucleus in their apical portion forming clusters and accompanied by bell-shaped Sertoli cells.

Cylindrical cells with a nucleus in their apical portion and accompanied by elongated Sertoli cells linked to the basal portion.

Cylindrical cells, the nucleus starts to migrate to the basal portion, being accompanied by elongated Sertoli cells connected to its basal portion.

Cylindrical and elongated cells with nucleus almost in their basal portion accompanied by elongated Sertoli cells attached to their basal portion.

Cylindrical and elongated cells with a nucleus in their basal portion undergoing a spiraling process, inserting themselves into the Sertoli cells that have an oval shape with a large amount of cytoplasm.

Elongated cells with a fusiform nucleus in their basal portion inserting into the Sertoli cells with an oval shape, and the presence of cytoplasmic portions migrating along with the cell.

Spermatozoa, being long cells with a fusiform nucleus inserted in the oval-shaped Sertoli cells.

\section{CONCLUSION}

After a qualitative and quantitative study, it was possible to describe the gametogenesis of the hermaphrodite snail B. glabrata, bringing all morphological characteristics of the female and male germinative cells and Sertoli cells throughout its development, bringing morphological characteristics of oocytes and spermatocytes and histomorphometric parameters of all stages of the oocyte development. These parameters can be used as a tool for assessing the impact and toxicity of different pollutants in the reproductive tissue of $B$. glabrata when used as an environmental biomonitor, as well in public health researches that aim to evaluate new substances to control the intermediate host snail of Schistosoma mansoni.

Funding: This research was funded by Fundação de Amparo à Pesquisa do Estado de Goiás (FAPEG, edital no 04/17 - Programa Pesquisa para o SUS: Gestão Compartilhada em Saúde - FAPEG/SES-GO/CNPq/MS-DECIT/2017PPSUS/GO), Coordenação de Aperfeiçoamento de Pessoal de Nível Superior (CAPES) funding code 001, and by Conselho Nacional de Desenvolvimento Científico e Tecnológico (CNPq).

Conflicts of Interest: The authors declare no conflict of interest. 


\section{REFERENCES}

1. Nakadera Y, Koene JM. Reproductive strategies in hermaphroditic gastropods: conceptual and empirical approaches. Can J Zoo. 2013 Mar 25;91(6):367-81. doi:10.1139/cjz-2012-0272

2. Almeida HK, De Gimenez J. Gonad characterization and reproductive seasonality in Siphonaria lessonii (Gastropoda: Heterobranchia) from the southwestern Atlantic Ocean. Invertebr Biol. 2018 sept 14;137:264-77. https://doi.org/10.1111/ivb.12225

3. Heller Joseph. Hermaphroditism in molluscs. Biol J Linn Soc. 1993 jan;48(1):19-42.

4. Collin Rachel. Phylogenetic patterns and phenotypic plasticity of molluscan sexual systems. Integr Comp Biol. 2013 Oct;53(4):723-35. https://doi.org/10.1093/icb/ict076

5. Amorim J, Abreu I, Rodrigues P, Peixoto D, Pinheiro C, Saraiva A, et al. Lymnaea stagnalis as a freshwater model invertebrate for ecotoxicological studies. Sci Total Environ. 2019 june 15;669:11-28. https://doi.org/10.1016/j.scitotenv.2019.03.035

6. Caixeta MB, Araújo PS, Gonçalves BB, Silva LD, Grano-Maldonado MI, Rocha TL. Toxicity of engineered nanomaterials to aquatic and land snails: A scientometric and systematic review. Chemosphere. 2020 Dec;260:127654. https://doi.org/10.1016/j.chemosphere.2020.127654

7. Radwan MA, El-Gendy KS, Gad AF. Biomarker responses in terrestrial gastropods exposed to pollutants: A comprehensive review. Chemosphere. 2020 Oct;257:127218. https://doi.org/10.1016/j.chemosphere.2020.127218

8. Caixeta MB, Araújo PS, Rodrigues CC, Gonçalves BB, Araújo OA, Bevilaqua GB, et al. Risk assessment of iron oxide nanoparticles in an aquatic ecosystem: a case study on Biomphalaria glabrata. J Hazard Mater. 2021 Jan 5;401:123398. https://doi.org/10.1016/j.jhazmat.2020.123398

9. Melo AO, Santos DB, Silva LD, Rocha TL, Bezerra JCB. Molluscicidal activity of polyhexamethylene biguanide hydrochloride on the early-life stages and adults of the Biomphalaria glabrata (Say, 1818). Chemosphere. 2019 Feb;216:365-71. https://doi.org/10.1016/j.chemosphere.2018.10.035

10. Oliveira-Filho E, Muniz D, Carvalho E, Cáceres-Velez P, Fascineli M, Azevedo R, et al. Effects of AgNPs on the snail Biomphalaria glabrata: Survival, Reproduction and Silver Accumulation. Toxics. 2019 Mar 1;7(1):12. https://doi.org/10.3390/toxics7010012

11. Vasconcelos-Lima M, Andrade Pereira MI, Cabral Filho PE, Nascimento de Siqueira W, Milca Fagundes Silva HA, França EJ, et al. Studies on toxicity of suspensions of CdTe Quantum Dots to Biomphalaria glabrata Mollusks. Environ Toxicol Chem. 2019 Oct;38:2128-36. https://doi.org/10.1002/etc.4525

12. Oliveira-Filho EC, Nakano E, Tallarico LF. Bioassays with freshwater snails Biomphalaria sp.: from control of hosts in public health to alternative tools in ecotoxicology. Invertebr Reprod Dev. 2017 Jan 11;61:49-57. https://doi.org/10.1080/07924259.2016.1276484

13. Tallarico LF. Freshwater gastropods as a tool for ecotoxicology assessments in latin america. Am Malacol Bull. 2015 Dec 23;33(2):330-6. https://doi.org/10.4003/006.033.0220

14. Tallarico LF, Borrely SI, Hamada N, Grazeffe VS, Ohlweiler FP, Okazaki K, et al. Developmental toxicity, acute toxicity and mutagenicity testing in freshwater snails Biomphalaria glabrata (Mollusca: Gastropoda) exposed to chromium and water samples. Ecotoxicol Environ Saf. 2014 Dec;110:208-15. https://doi.org/10.1016/j.ecoenv.2014.09.005

15. Ansaldo M, Nahabedian DE, Di Fonzo C, Wider EA. Effect of cadmium , lead and arsenic on the oviposition , hatching and embryonic survival of Biomphalaria glabrata. Sci Total Environ. 2019 Mar 1;407(6):1923-8. https://doi.org/10.1016/j.scitotenv.2008.12.001

16. Araújo PS, Caixeta MB, Brito RS, Gonçalves BB, Silva SM, Lima ECO, et al. Molluscicidal activity of polyvinylpyrrolidone (PVP)-functionalized silver nanoparticles to Biomphalaria glabrata: Implications for control of intermediate host snail of Schistosoma mansoni. Acta Trop. 2020 Nov;211:105644. https://doi.org/10.1016/j.actatropica.2020.105644

17. Gourmelon A, Ahtiainen $Æ J$. Developing test guidelines on invertebrate development and reproduction for the assessment of chemicals, including potential endocrine active substances - The OECD perspective. Ecotoxicology. 2007 Feb;16(1):161-7. https://doi.org/10.1007/s10646-006-0105-1

18. Einin HM, Ali RE, Gad El-Karim RM, Youssef AA, Abdel-Hamid H, Habib MR. Biomphalaria alexandrina: a model organism for assessing the endocrine disrupting effect of 17ß-estradiol. Environ Sci Pollut. Res. 2019 June 13;26:23328-36. https://doi.org/10.1007/s11356-019-05586-0

19. Oliveira-Filho EC, Filho JS, Novais LA, Peternele WS, Azevedo RB, Grisolia CK. Effects of $\mathrm{Y}-\mathrm{Fe}_{2} \mathrm{O}_{3}$ nanoparticles on the survival and reproduction of Biomphalaria glabrata (Say, 1818) and their elimination from this benthic aquatic snail. Environ Sci Pollut Res. 2016 Jun 9;23:18362-8. https://doi.org/10.1007/s11356-016-6998-1

20. NE, Salama WM. The endocrine disruptor effect of the herbicides atrazine and glyphosate on Biomphalaria alexandrina snails. Toxicol Ind Health. 2016 Apr;32:656-65. https://doi.org/10.1177/0748233713506959 
21. Czech $\mathrm{P}$, Weber K, Dietrich $\mathrm{D}$. Effects of endocrine modulating substances on reproduction in the hermaphroditic snail Lymnaea stagnalis. L Aquat Toxicol. 2001 Jul;53:103-14. https://doi.org/10.1016/S0166-445X(00)00169-7

22. Duft M, Schmitt C, Bachmann J, Brandelik C, Schulte-Oehlmann U, Oehlmann J. Prosobranch snails as test organisms for the assessment of endocrine active chemicals-an overview and a guideline proposal for a reproduction test with the freshwater mudsnail Potamopyrgus antipodarum. Ecotoxicology. 2017 Feb;16(1):16982. https://doi.org/10.1007/s10646-006-0106-0

23. Khangarot BS, Das S. Effects of copper on the egg development and hatching of a freshwater pulmonate snail Lymnaea luteola L. J Hazard Mater. 2010 July 15;179:665-75. https://doi.org/10.1016/j.jhazmat.2010.03.054

24. Schmitt $C$, Balaam J, Leonards $P$, Brix R, Streck G, Tuikka A, et al. Characterizing field sediments from three european river basins with special emphasis on endocrine effects - A recommendation for Potamopyrgus $\begin{array}{lllll}\text { antipodarum as test } & \text { organism. } & \text { Chemosphere. } & 2010 & \text { Jun;80(1):13-19. }\end{array}$ https://doi.org/10.1016/j.chemosphere.2010.03.050

25. Zrinyi Z, Maasz G, Zhang L, Vertes A, Lovas S, Kiss T. Effect of progesterone and its synthetic analogs on reproduction and embryonic development of a freshwater invertebrate model. Aquat Toxicol. 2017 Sep;190:94103. https://doi.org/10.1016/j.aquatox.2017.06.029

26. Zhou X, Yang Z, Luo Z, Li H, Chen G. Endocrine disrupting chemicals in wild freshwater fishes : Species, tissues, sizes and human health risks. Environ Pollut. 2019 Jan;244:462-8. https://doi.org/10.1016/j.envpol.2018.10.026

27. Rozenblut-kościst B, Ogielska M, Hahn J, Kleemann D, Kossako R, Tamschick S, et al. Impacts of the synthetic androgen trenbolone on gonad differentiation and development - comparisons between three deeply diverged anuran families. Sci Rep. 2019 Jul 03;9:9623. https://doi.org/10.1038/s41598-019-45985-4

28. Silva RF, Cubas JJM, Moraes J,. [Histological aspects of the hermaphroditic gonads of Biomphalaria glabrata and Bradybaena similaris (Mollusca, Gastropoda, Pulmonata)]. Pap Avulsos Zool. 2009;49(33):459-66. https://doi.org/10.1590/s0031-10492009003300001

29. Trigwell JA, Dussart GBJ, Vianey-Liaud M. Pre-copulatory behaviour of the freshwater hermaphrodite snail Biomphalaria glabrata (Say, 1818) (Gastropoda: Pulmonata). J Molluscan Stud. 1997 Feb;63:116-20. https://doi.org/10.1093/mollus/63.1.116

30. Menezes V, Tunholi-alves VM, Teixeira A, Garcia S, Maldonado A, Seixas W, et al. Evaluation of the mitochondrial system in the gonad-digestive gland complex of Biomphalaria glabrata (Mollusca, Gastropoda) after infection by Echinostoma paraensei (Trematoda, Echinostomatidae). J Invertebr Pathol. 2016 May;136:136-41. https://doi.org/10.1016/j.jip.2016.04.003

31. Santos Bonfim TC, Tunholi-Alves VM, Martins FG, Mota EM, Maldonado Jr A, Pinheiro J, et al. Biological and histological changes in reproductive patterns of Biomphalaria glabrata experimentally co-infected by Echinostoma paraensei and Angiostrongylus cantonensis. Exp Parasitol. 2018 Oct;195(4),66-70. https://doi.org/10.1016/j.exppara.2018.10.005

32. Faro MJ, Perazzini M, dos Reis Corrêa L, Mello-Silva CC, Pinheiro J, Mota EM, et al. Biological, biochemical and histopathological features related to parasitic castration of Biomphalaria glabrata infected by Schistosoma mansoni. Exp Parasitol. 2013 Jun;134(2):228-34. https://doi.org/10.1016/j.exppara.2013.03.020

33. Aisemberg J, Nahabedian DE, Wider EA, Guerrero RV. Comparative study on two freshwater invertebrates for monitoring environmental lead exposure. Toxicology. 2005 May 15;210(1):45-53. https://doi.org/10.1016/j.tox.2005.01.005

34. Ibrahim AM, Ahmed AK, Bakry FA, Rabei I, Abdel-ghaffar F. Toxicological impact of butralin, glyphosateisopropylammonium and pendimethalin herbicides on physiological parameters of Biomphalaria alexandrina snails alexandrina snails. Molluscan Res. 2019 Apr 07; 39(3):224-33. https://doi.org/10.1080/13235818.2019.1592296

35. OECD. OECD Test No. 243: Lymnaea stagnalis Reproduction Test. OECD Guidelines for the Testing of Chemicals, Section 2 OECD Publishing, Paris. 2016. https://doi.org/https://doi.org/10.1787/9789264264335-en.

36. de Jong-Brink M, de Wit A, Kraal G, Boer HH. A light and electron microscope study on oogenesis in the freshwater pulmonate snail Biomphalaria glabrata. Cell Tissue Res. 1976 Aug 20;171(2):195-219. https://doi.org/10.1007/BF00219406

37. de Jong-brink M, Boer HH, Hommes TG, Kodde A. Spermatogenesis and the role of sertoli cells in the freshwater snail Biomphalaria glabrata. Cell Tiss Res. 1977 Jun 20;181(1):37-58. doi: 10.1007/BF00222773.

38. Paraense WL. [History of the genus Biomphalaria, morphology and morphological systematics], in: Carvalho OS, Coelho PMZ, Lenzi HL, editors. Schistosoma Mansoni and Esquistossomose: Uma Visão Multidisciplinar. Rio de Janeiro: FIOCRUZ; 2008. p. 285-308. https://doi.org/https://doi.org/10.7476/9788575413708

39. Tomé LA, Ribeiro AF. Functional organization of the carrefour in the reproductive tract of B. tenagophila (Mollusca, Planorbidae). Inverteb Rep Dev. 1997 Jul 25;34(1):25-33. https://doi.org/10.1080/07924259.1998.9652350 
40. Omran Nel-S. Testosterone, gonadotropins and androgen receptor during spermatogenesis of Biomphalaria alexandrina snails (Pulmonata: Basommatophora). Rep Biol. 2012 Nov;12(3):301-8. doi:10.1016/j.repbio.2012.10.002

41. Maltz T K. Reproductive system development and annual cycle of gonad activity in Helicodonta obvoluta (O. F. Müller, 1774) (Gastropoda: Pulmonata: Helicidae s. lat.). Folia Malacologica. 2003;11(1-2):23-31. doi:10.12657/folmal.011.002.

42. Paraense WL. A bird's eye survey of central american planorbid molluscs. Mem Inst Oswaldo Cruz. 2003 Jan;98(1):51-67. https://doi.org/10.1590/S0074-02762003000100008

43. Paraense WL. Biomphalaria tenagophila Guaibensis ssp. n. from Southern Brazil and Uruguay (pulmonata: Planorbidae). Mem Inst Oswaldo Cruz. 1984 Dec;79(4):465-69. https://doi.org/10.1590/S007402761984000400012

44. Paraense WL. Biomphalaria occidentalis sp.n. from South America (Mollusca basommatophora pulmonata). Mem Inst Oswaldo Cruz. 1981 June;76(2):199-211. https://doi.org/10.1590/S0074-02761981000200011

45. Paraense WL, Deslandes N. Observations on the morphology of Australorbis nigricans. Mem Inst Oswaldo Cruz. 1955 May;53(1):121-34. https://doi.org/10.1590/S0074-02761955000100012

46. Brasil. [Surveillance and control of molluscs of epidemiological importance: technical guidelines]: Programa de Vigilância e Controle da Esquistossomose (PCE). 2nd ed. Brasilia (DF): Ministério da Saúde; 2008.

47. Paraense WL. [Planorbid fauna of Brazil]. Lacaz CS, Baruzzi RG, Siqueira Jr W, editors. Introduçăo á geografia médica do Brasil. Săo Paulo: Edgard Blücher/Edusp; 1972. p. 213-39.

48. Coelho PMZ, Caldeira RL. Critical analysis of molluscicide application in schistosomiasis control programs in Brazil. Infec Dise Poverty. 2016 Jul 4;5(57):1-6. https://doi.org/ 10.1186/s40249-016-0153-6

49. Davie E, Petersen J. Environmental control of cell size at division. Curr Opin Cell Biol. 2012 Dec;24(6):838-44. https://doi.org/10.1016/j.ceb.2012.08.003

50. Tallarico LF, Okazaki K, Kawano T, Pereira CAB, Nakano E. Dominant lethal effect of 60Co in Biomphalaria glabrata (Say, 1818). Mutat Res. 2004 Jul 11;561(1-2):139-45. https://doi.org/10.1016/j.mrgentox.2004.05.002.

2021 by the authors. Submitted for possible open access publication under the terms and conditions of the Creative Commons Attribution (CC BY NC) license (https://creativecommons.org/licenses/by-nc/4.0/). 